\title{
The Impact of the Use of Village Funds on Sustainable Agricultural Development
}

\author{
Kurnia Suci Indraningsih ${ }^{1, *}$, Wini Nahraeni ${ }^{2}$, Adang Agustian $^{1}$, Endro Gunawan ${ }^{1}$, and \\ Syahyuti ${ }^{1}$ \\ ${ }^{1}$ Researcher at Indonesian Center for Agricultural Socio-Economics and Policy Studies \\ ${ }^{2}$ Lecturer at Djuanda University, Bogor, Indonesia
}

\begin{abstract}
The priority of the Village Fund is for the village development programs and activities. The relatively large value of Village Funds in Indonesia is expected to affect the welfare of village communities and also sustainable. The problem is that not all villages have the same level of development, so the management of village resources cannot be uniformed. The objective of this paper is to analyze the impact of the Village Fund, especially for agricultural development. The location of this study included three village typologies in the West Java provinces, DI Yogyakarta, Riau, East Kalimantan, and Gorontalo. There are 166 respondents selected, consisted of (1) policymaking institutions and the service institutions leader; (2) key informants; (3) farmer groups; and (4) extension agents. Data were analyzed by descriptive explanative. The results showed that the Village Fund affected increasing farmers' production and income. The process of transporting production facilities and yields has become easier through the improvement of infrastructure farming and facilities. In the future, Village Funds aside for infrastructure development should be allocated for community economic empowerment, i.e., training in agricultural, livestock, and fisheries skills according to the village's potential, so that it can support sustainable agricultural development in rural areas.
\end{abstract}

\section{Introduction}

Village development program objectives are prioritized to reduce levels national inequality and manifested in the form of needs assessment village community in the form of improving development and maintenance of infrastructure and the environment based on technical capabilities and available local resources; the quality and access to basic services; development and use of appropriate technology for economic progress; and improving the quality of order and peace of the village community based on its needs, and development of a productive-scale agricultural economy. The paradigm of rural development in Indonesia shows a very significant shift after the existence of Law Number 6 of 2014 concerning Villages. This is reflected in the existence of APBD funds that are transferred directly to the village and the existence of profit-sharing funds from the original Regency revenue for the village [1].

\footnotetext{
${ }^{*}$ Correspponding author: kurniasuci@yahoo.com
} 
The Central Government seeks to strengthen village governance as actors of development through village regulations as stipulated in Law No. 6/2014 on Village. In Article 3, there is a village regulation based on recognition, subsidiarity, diversity, togetherness, cooperation, kinship, deliberation, democracy, independence, participation, equality, empowerment, and sustainability. The law is followed up by Government Regulation No. 60/2014 concerning Village Funds Sourced from the State Budget and several articles were amended as outlined in Government Regulation No. 22/2015 concerning Amendment to this regulation.

Government Regulation No. 60/2014 does not limit local initiatives in designing priority development programs/activities as outlined in the RKPDesa and APBDesa documents, but rather provides a priority view of the use of Village Funds so that villages still have room to be creative in making village programs/activities by their authority, analysis of priority needs and the resources it has.

Village development is intended to improve the welfare of rural communities and the quality of human life and alleviate poverty. The priority for the use of the Village Fund is directed at the implementation of village development programs and activities. In the context of community empowerment, priority for the use of the Village Fund is allocated to fund activities aimed at increasing the capacity of villagers or village communities in entrepreneurial development, increasing income, and expanding the economic scale of individual residents or community groups and villages.

The relatively large value of the Village Fund plus its mass distribution covering all villages in Indonesia needs to be used appropriately so that it has an impact on the welfare of the village community. The economic sector being developed needs to be adjusted to the potential and aspirations of the village community concerned. The Village Fund is intended to improve welfare and equitable village development through increasing public services in the village, advancing the village economy, overcoming development gaps between villages, and strengthening village communities as the subject of development. Besides, with the existence of village funds, it is hoped that agricultural development in rural areas can run dynamically and sustainably.

The problem that arises is that not all villages have the same level of progress for all regions in Indonesia. There are three village typologies, namely: (1) underdeveloped and/or very underdeveloped villages, (2) developing villages, and (3) developed villages and / or independent villages. These three village typologies cannot be uniform in the management of village resources. This paper aims to analyze the impact of the Village Fund, especially for agricultural development.

\section{Methodology}

\subsection{Framework}

The government seeks to achieve equitable development through the implementation of the 3rd Nawacita, namely to build from the periphery and strengthen regions and villages within the framework of a unitary state. Acceleration of development in rural areas with villages as the main focus and locus of development. Strategies carried out through (1) Improving the quality of planning and implementation of village development through refocusing village development (4 priority village development programs: Village Superior Products or Prudes / Superior Products for Rural Areas or Prukades, Village BUM, pond, and Village Sports Facilities); (2) Consolidation in funding and activities in village development (Ministries / Institutions, Provincial / Regency / City Governments, BUMN, BUMD, and private sector); and (3) Coordination with the support of 19 ministries/agencies [2]. 
Several things need to be considered in optimizing the use of Village Funds. First, strengthen community involvement in planning and monitoring the use of Village Funds, as stipulated in article 68 of Law No.6 / 2014 concerning Villages regarding the community's right to request and obtain information from the village government and supervise the activities of implementing village governance, implementing village development, coaching. Village community, and the empowerment of village communities. Community involvement is the most dominant factor because the community knows the needs of the village and directly witnesses the progress of village development and implementation, for this, it is necessary to activate youth organizations and social community organizations in the village.

Second, empowering the existence of the Village Consultative Body (BPD) in absorbing aspirations and encouraging the community to be actively involved in village development, from inventorying village needs, planning activities, and managing funds to accountability. Third, optimizing the role of development by the Village Community Empowerment Service and the District Regional Financial Management Agency in the form of technical guidance and assistance related to village governance and village financial management which is more like increasing the competence of village heads, apparatus, and village communities to prevent errors and irregularities in managing the Village Fund. Fourth, increasing the role of the Government Internal supervisory apparatus, both the District Inspectorate, the Provincial Inspectorate, and the BPKP in overseeing the use of Village Funds. By optimizing the use of funds in rural areas with the active involvement of the community, it will also ensure more sustainable aspects of development in the village.

Currently, the focus of developing and emerging economies is economic growth and food security included the sustainable development. The level of agricultural sustainability varies across different regions, countries, and in different periods [3] Despite the adoption of sustainable agricultural practices that enhance farmers' productivity and improve the environment, there is still a lack of supply of food to the world's population [4],[5]. Economic, social, and economic goals at some level can synergize. However, under certain conditions in the field, the three of them can compete with each other and do not support each other. If this happens, the concept of sustainability leads to the need for a correct balance between the parties involved in it. Meanwhile, according to [6] that agricultural development is a process aimed at always increasing agricultural production for each consumer, which at the same time increases the income and business productivity of each farmer by increasing the amount of capital and skills, to increase human intervention. in the development of plants and animals. In the context of sustainable agriculture, there will be the ability to remain productive while maintaining the resource base.

By the provisions of Government Regulation No. 60/2014 Article 19 paragraph (2) states that Village Funds are prioritized for community development and empowerment. By considering the circumstances, geographical, sociological, anthropological, economic, and ecological characteristics of the village, as well as changes or developments in village progress, this study analyzes the impact of the Village Fund on three typologies of villages with an agricultural-based economic system: (1) underdeveloped villages and / or very underdeveloped, (2) developing villages, and (3) developed villages and / or independent villages. A comparison of the impact of village funds was carried out in villages with the same typology.

\subsection{Research Locations and Respondents}

The study locations include Java and Outer Java. Several Provinces were selected purposively based on the Village Developed Index (IDM) data set by the Ministry of Villages, Development of Disadvantaged Regions, and Transmigration through the Regulation of the Minister of Villages, Development of Disadvantaged Areas, and 
Transmigration No. 2 of 2016. IDM data is a village typology mapping based on the level of village progress for prioritizing the use of Village Funds. With the above considerations, the selected research locations are West Java Province and Yogyakarta Special Region to represent Java Island, Riau Province, East Kalimantan, and Gorontalo represent Outside Java. Each province selected three village typologies (lagging, developing, and advanced).

Respondents in this research activity are (1) leaders of policy-making institutions, service institutions related to the field of study from the center to the regions (Central, Provincial and Regency levels); (2) key informants (village officials); (3) farmer groups; and (4) extension, workers. The total number of respondents was 166.

\subsection{Data and Analysis Methods}

Data collected in the form of primary data and secondary data. Primary data is the main data used to answer the study objectives, while secondary data is complementary data. Primary data were collected directly from respondents, namely all stakeholders associated with the study using a structured questionnaire. Primary data is the main data because we use for analytical and to be frame in the logical framework of the research.

The coverage of primary data consists of quantitative data and qualitative data (data to explain the observed phenomena), both those obtained by policy-making institutions and service agencies in the provincial, district, sub-district, and village agriculture agencies. Secondary data were obtained from agencies, such as Directorate of Village Economic Business Development, Directorate of Village Facilities and Infrastructure Development, Directorate of Village Community Empowerment, Ministry of Health Data and Information Center, and related technical offices. Besides that, secondary data were obtained from the media, both print and electronic.

The analytical method used is "Gap Analysis" comparing the production variables and farmer income before and after the existence of village funds, namely in 2014 and 2017. The justification for 2014 and 2017 was taken because in 2014 village funds began to be rolled out and the progress was seen three years later. in 2017 (research was conducted in 2018).

The variables observed included village characteristics (village potential, farmer institutions, main commodities, cropping patterns, and main source of livelihood for the population), production and farmer income. Apart from that, the socio-economic conditions of the village before and after the existence of village funds include planting area, planting pattern, kiosk and access to agricultural production facilities, access to production facilities, and the number of reservoirs. The data and information are sorted and analyzed using a quantitative descriptive approach.

\section{Results and Discussion}

\subsection{Characteristics of Sample Villages}

\subsubsection{West Java Province}

The sample village is Mekarmukti Village, which is $13 \mathrm{~km}$ from the capital of the Cibalong District. One of the farmer groups in this village is the Karya Mandiri Farmer Group, which was founded in 2012. The dominant cropping pattern is rice-secondary crops, but most farmers also plant corn, soybeans, bananas, albizia wood, and rubber. The superior products of this village are rubber and banana. The existence of a Village-Owned Enterprise in this village makes it easier for rubber farmers to obtain business capital and market the processed 
rubber / leum products. The amount of the loan is IDR 1,000,000, which is paid in installments every two weeks

Binakarya Village is one of the villages in Banyuresmi Subdistrict which belongs to a developing village typology. The area of this village is 667.50 hectares and is $2.5 \mathrm{~km}$ to the subdistrict capital and $15 \mathrm{~km}$ to the district capital. The main crops in Binakarya Village are rice and corn. The cultivated commodity is highly dependent on water availability because most of the land is rainfed land. Thus, in general, the cropping pattern in Binakarya Village is rice-corn / intercropping with fallow-curly chilies. If the availability of water is adequate, the cropping pattern will be paddy-rice fallow.

The economy in Pamekarsari Village is generally dominated by the agricultural sector which is still managed conventionally. Pamekarsari Village's agricultural products for wetlands (rice fields) are still dominated by rice, maize, and secondary crops. This is related to the soil structure suitable for rice, maize, and secondary crops, as well as the availability of water, especially during the dry season. In Pamekarsari Village, there are five Poktans, namely: Tamansari, Paguyuban, Sari Makmur, Bunga Mekar, and Mekarsari. In 2016, the West Java province contributed approximately $15 \%$ of the total production of paddy rice in Indonesia [7].

\subsubsection{Yogyakarta Province}

Melikan Village consists of 13 padukuhan. Melikan village is included in underdeveloped villages, because: (1) access to basic service centers is relatively far away, (2) the disaster response program has not yet reached the village, and (3) the farming community still relies on the rainy season in carrying out farming activities. The agricultural commodities suitable for planting in Melikan Village are rice, corn, cassava, and peanuts. Currently, farmers have been urged to reduce the use of inorganic fertilizers (chemical fertilizers) and switch to manure which is processed into organic fertilizer. Government assistance in the form of rice and corn seeds has been provided to 103 farmer groups within the Rongkop District.

Margoluwih Village is an agricultural village and tile industry center. This village has abundant water sources that come from the Mataram ditch. Margoluwih Village consists of 14 hamlets with an area of 500 hectares. In this area, the agricultural sector is very advanced, namely the existence of the management of the Mina Padi farming in the Murakabi Farmer Group which has been recognized internationally by the FAO.

The cropping pattern in a year in Margoluwih Village is rice-paddy and / or rice-paddycrops in rotation. The most widely planted rice varieties are Ciherang, Situ Bagendit, and IR 64. In planting season I and planting season II the cropping pattern is still rice, but in planting season III the commodity planted is usually secondary crops. This is related to the distribution of water arranged by blocks. Setting water as a source of irrigation is one of the keys to the success of agriculture in Margoluwih Village. Currently, black rice has been developed in collaboration with a private company in Jogjakarta.

Ngaglik sub-district is a development urban, but in the northern region, there are still many farmers. In this sub-district, there are six villages, one of the villages with a developed village typology is Sardonoharjo Village. 70\% of Sardonoharjo Village is an agricultural area with limited water sources. In Sardonoharjo Village, the two farmer groups studied were the Candi Lama and Makmur Farmers Group, both of whom were members of Gapoktan Ngudi Waluyo. This Gapoktan has 22 farmer groups. The Candi Lama Farmer Group has 33 members and the Makmur Farmer Group has 35 farmers. The economy in Sardonoharjo Village is dominated by rice and secondary crops, with a rice-paddy-secondary / horticultural cropping pattern (maize, peanuts, chilies, eggplant). Most (60\%) of the rice-paddy cropping pattern are cultivated by old farmers. Water sources are a barrier in this village, therefore if the weather is uncertain, the dominant cropping pattern is rice-secondary crops after it is laid. 
[8] Farmers in India grow agricultural commodities by considering the type of soil, weather or rainy season, and market conditions that are predicted to provide benefits for farmers, thereby increasing farmers' income.

\subsubsection{Riau Province}

Two sample districts in Riau Province are Kampar and Siak Districts. Kampar Regency with a population of 800,000 people spread across 241 villages / sub-districts ( 21 sub-districts) has potential in the fields of plantations (oil palm and rubber), food crops, and horticulture. Currently, the palm oil plantation in Kampar Regency has a land area of 241.5 thousand hectares with the potential for crude palm oil (CPO) of 966 thousand tons. The leading commodities in the horticulture sector are oranges and pineapples (1,075 ha), while for food crops in the form of rice with a planted area of 1,075 ha. The problems faced by farmers in Kampar Regency are the capital and marketing of agricultural products, pineapples produced by farmers have no market guarantee.

The Kampar Regency Government and the National Private Company have signed the MoU for three superior products in rural areas. First, Mou and PT Fruit Ing handled pineapple and orange fruit commodities. Second, the MoU with PT Haqi Corpora Putra deals with livestock and horticulture, namely for cattle, buffalo, and corn commodities. Third, the MoU with PT Sinar Mas handles the plantation sector. Fruit Indonesia has collaborated in developing superior products in rural areas. Construction of embungs has been carried out in Koto Kampar Hulu District (two reservoirs) and Rumbio Jaya District (two reservoirs). Kualu Nenas Village has a superior product in rural areas in the form of pineapples, considering that around $70-80 \%$ of the community has pineapple plants.

In Siak Regency, there are tapioca companies with a capacity of 400 tons/day, operationally only capable of producing 200 tons/day. Thai cassava can produce a maximum of 150 tonnes/ ha (with intensification), the average production is $50 \mathrm{~kg} / \mathrm{ha}$, while the village type cassava is only $25 \mathrm{~kg} / \mathrm{ha}$, the price received by farmers is IDR $1,000 / \mathrm{kg}$. The cost of intensive cassava farming reaches IDR $18 \mathrm{million} / \mathrm{ha}$ for the purchase of production facilities and wages for labor. Currently, farmers need cassava seeds that are planted with intensification. In the future, there will be opportunities for cooperation between farmersvillage-owned enterprises and companies. Paper companies need tapioca flour for about $30 \%$ of the production component as much as 200 tons/day.

The sample villages in Riau Province are Gobah Village (underdeveloped village), Kualu Nenas Village (developing village), and Bungaraya Village (developed village). The area of Gobah Village is $663 \mathrm{Ha}$ with 150 ha of rainfed rice fields, no irrigation, the main products are oil palm and rubber, local rice (Datuk Dukun variety) is planted once/year (six months), seedlings in August and planting in September, without tillage, the production is around 4-5 tonnes/ha, the selling price of milled dry unhulled rice is IDR $4,000 / \mathrm{kg}$ or IDR $10,000 / \mathrm{kg}$ of rice, the cost of maintaining rice is considered to be greater than the yield. Minimum farmer land ownership is 0.25 ha (subsistence farming) and a maximum of 1.0 ha. The wages for workers from 07.00-16.00 are IDR 60,000 for women, while for men, IDR 125,000. The damp in this village is not yet a priority scale, because there are rivers and lakes. Currently two-wheeled vehicles have entered Gobah Village, farmers are proposing three-wheeled vehicles. In Gobah Village, there are five food farmer groups, one horticultural farmer group, three plantation groups, and one fishery group.

\subsubsection{East Kalimantan Province}

Loa Lepu Village is one of the villages located in Tenggarong Sebrang District, Tenggarong Regency. This village is in an underdeveloped village typology. As an underdeveloped 
village, many of the farmers in Loa Lepu Village are still subsistence. Apart from not yet developed farming procedures, the farmer and agricultural institutions are not yet wellestablished. The main problem that you feel is the pollution from coal mines which is very disturbing to agriculture.

One of the developing villages in Tenggarong Sebrang District is Bukit Pariaman Village. Tenggarong Seberang and Loa Kulu Subdistricts are the main food barns of Kutai Kartanegara Regency, and rice is the main production. Loa Kulu District is a sub-district located in the central area of Kutai Kartanegara Regency, East Kalimantan. Loa Kulu District has an area of $1,405.7 \mathrm{~km} 2$ which is divided into 15 villages. One of the villages that have entered the advanced village typology is Loa Kulu Kota Village.[9] Another village that is classified as advanced in the Java area is Banguntapan Village in Bantul Regency where village funds have had a positive impact according to community needs, both related to physical and non-physical development.

The selected villages in Gorontalo Province are Duwanga Village (underdeveloped village), Daenaa Village (developing village), and Hulawa Village (developed village). The planting pattern that is commonly used by farmers in Duwanga Village is green beans. The price of rice seeds has reached IDR $8,500 / \mathrm{kg}$ and currently, there are no longer subsidized seeds. Farmers use derivative seeds more than labeled seeds, so there has been a decline in rice productivity in the last two years.

Limboto Barat sub-district consists of 10 villages, eight developing villages, and two underdeveloped villages. Daenaa Village has an agricultural land area of 360 ha with a population of 1,044 families, 70 percent of whom are dryland farmers who cultivate corn commodities on an area of 705 ha. Daenaa Village has 22 farmer groups that need 90 tons of urea.

The Maju Bersama Farmer Group is one of the farmer groups in Daenaa Village under the Bukit Harapan Farmer Group, with a total of 22 farmer groups. This group was founded in 2007 but has not been legally incorporated until now. The number of members is 36 farmers. The dominant commodity grown in this group is maize. The program received by the Department of Agriculture is local maize seeds and starting in 2006 they were assisted with hybrid maize seeds.

Hulawa Village has one Gapoktan called Gapoktan Huyula (cooperation). One of the farmer groups is Tunggula. This group was founded in 2008 and legalized through a Village Regulation in 2008. The number of members is 35 people, with the dominant commodity in the group is horticulture. The dominant cropping pattern is tomato - chili cucumber. Water shortages were overcome by building boreholes funded by Balai Sungai in 2015. According to the results of the interviews, the Village Fund which is directly related to the agricultural sector is the tertiary channel that was built in 2017 and 2018. [10] Village funds are used for building facilities and infrastructure, develop local economic potential, and village resources in a sustainable manner. Village government. Prioritize the construction of facilities and infrastructure that is beneficial for the daily activities of the village community.

\subsection{Production and Income}

The 15 sample villages in the study area, it can be seen that the Village Fund has a positive impact on rural development, both on physical development and community empowerment. The use of Village Funds in the sample villages has similarities, namely, it is used for village infrastructure development such as paving roads, building bridges, making irrigation channels, making taluds, and training. The allocation and use of the Village Fund in most villages are directed towards infrastructure to facilitate transportation so that it is hoped that the village economy will increase, and only a small portion is allocated for agricultural commodities. The results of the study [9] indicated that in Bantul Regency, village funds 
have a positive impact on development, both physical and non-physical according to community needs. The management of the village funds has fulfilled the principle of accountability. This is because the use of village funds can be accounted from beginning to end.

The 15 villages studied, if it is related to the impact of the Village Fund on agriculture, it has not been much allocated specifically for farmer groups. However, several sample villages have allocated Village Funds for agricultural activities. These activities include training in the manufacture of organic fertilizers, chicken farming, procurement of soursop seeds, vegetable seeds (long beans, chilies, bitter gourd, tomatoes, eggplant), as well as red tilapia fish breeding, poultry farming, black rice, baby cucumber and cattle fattening through a business entity. Village-owned. Also, the Village Fund is allocated for the construction of drying floors and procurement of tractors. Based on the results of interviews with farmer groups, in general, the Village Fund assistance is allocated indirectly through farmer groups, relatively not touching farmer groups, but the benefits can be felt by farmers.

The impact of the Village Fund has not been seen significantly, given the absence of an increase in the added value of agricultural products. The development of food crops and horticulture in almost all the villages studied came from the Agricultural Service programs which were given directly to the villages through farmer groups. From the village apparatus, several respondents stated that so far there has been no special Village Fund allocation for agriculture because there has been no submission from the farmer groups (Poktan) / Gapoktan. Also, the allocation of Village Funds for agriculture was constrained by a Joint Decree of four Ministers (overlapping with related agencies).

A statement made by [11] that the increase in Village Funds had less impact on reducing inequality. Also, the physical progress of village development is quite good, but the impact is not significant enough to directly address community needs. This is a result of the development of too much focus on the physical infrastructure of the village. Physical development in the village was carried out, but human development such as health, education, and improvement of basic skills was not carried out so that national problems such as stunting and maternal mortality/MMR were not overcome [12] in his research, it was concluded that Village Funds caused an increase in infrastructure and community empowerment programs, but Village Funds still had problems in its distribution and utilization so that Village Funds was not related to poverty reduction. A study conducted by [13] shows that the transfer of Village Funds is not significant in overcoming the problem of income inequality. The determining factors in overcoming the problem of income inequality in rural areas are education and the level of labor productivity in the agricultural sector. Furthermore, the development of irrigation infrastructure is enhanced to increase the productivity of agricultural products.

The causes of this are: (1) weak planning capacity in villages and (2) malfunctioning role of village assistants provided by the Central Government; (3) village facilitators do not help the quality of planning and reporting; and (3) the success of the integrated development model in various levels of villages. This is due to (1) inconsistencies in planning at the central and regional levels. Bappenas, Ministry of Home Affairs, Ministry of Villages, Development of Disadvantaged Regions and Transmigration each have ways of regulating the Regional Government and ways of regulating villages in matters of development and matters of priority setting; (2) the regulations in the village are still instructive and do not focus on empowering village communities to be able to build. The accountability for the use of the Village Fund is not maximal as a result of disharmony in the bottom-up development approach and the top-down approach: conflicting roles of planning regulators (Ministry of Home Affairs, Bappenas, Ministry of Villages, and Local Government) that confuse villages.

The impact of this was that villages avoided legal risks by spending cash only on easily accountable expenditures. For example, these activities are repairing village bridges, 
improving road aesthetics, when other needs are more urgent. Also, the Village Fund Allocation procedure is not based on justice, namely 90 percent of the Village Fund Allocation is a prorated allocation and the next 10 percent is based on variables of area size, population, poverty level, and distance to the district capital. Villages with a larger population will receive a lower per capita allocation than villages with smaller populations. The calculation of per capita allocation is used to predict the quality of village spending and the types of services that can be improved in the village given that the population, poverty rate, and area are the main determinants of the cost of service improvements as well as inequality in funding needs, in which a prosperous village will receive an excess. Allocation compared to poor villages.

Improper supervision of the use of the Village Fund will result in supervisory institutions such as the Finance and Development Supervisory Agency to treat villages like government agencies in Village Fund audits. This has resulted in the village prioritizing the tidiness of accountability reports rather than improving development. Community involvement in overseeing the use of the Village Fund is not well designed so that the community cannot participate in supervising it even though the accountability report is neat. The regional government and central government do not know about developments in the village, so the government does not know what the village needs. The existence of village assistants does not have an impact on improving the quality of village planning and reporting, because: (1) The recruitment pattern does not pay attention to the specific needs of the village. Local government and village officials are not involved in determining the skills required for the specific needs of the village, and (2) The distribution of facilitators is not yet by the targets per village. Currently, one assistant helps an average of four villages, even though the need for assistants is very intense considering that most of the understanding of substances such as health, entrepreneurship, is not owned by villagers

The allocation of the Village Fund can be used for agricultural activities, given that the priority for the use of Village Funds that are directly related to agriculture is reservoirs and superior village products/ superior products of rural areas. In reality, not all villages need pond. Superior village products/ superior products in rural areas, of course, in rural areas it can be ascertained that the superior products are related to agriculture.

The allocation and use of the Village Fund for agriculture can indirectly increase production and in some villages, it can increase the price of grain, but in other villages, it has not been able to increase the price of unhulled rice. The Village Fund disbursed, according to the farmers, is still not by the needs and expectations of the farmers. However, with the road paving, transportation of production facilities to agricultural land and marketing of the product has become easier. With the tertiary and quaternary channels, the water flow is smooth and can save labor costs. Until now, farmers have obtained agricultural production facilities such as fertilizers, tools, technology, and subsidies for seeds from the Agricultural Service program. However, according to farmers in Margoluwih Village, the output price policy is more attractive to farmers.

The previous research by [14] show that age of household head, off-farm income, farm size, and farm type were all associated with the likelihood of different productivity barriers. With regard to the impact of income on the probability of farmers facing agricultural production barriers, the results suggest that off-farm income may ensure cash flow and decrease income fluctuations. As a survival strategy, farmers often seek to diversify their sources of income and use other strategies to stabilise their earnings through off-farm activities [15,16, 17] Previous research by [18] analysing the warehouse receipt system in Cianjur and Subang District also showed that income had positive effects on adoption of agricultural innovations. The results also confirm the importance of farming experience. Other literature in this area confirms our findings and shows that more experienced farmers have a lower likelihood of facing specific agricultural production barriers. 
Table 1 shows data on rice production as a result of the indirect impact of using village funds. The allocation of Village Funds has an indirect impact on increasing production. The increase in production is directly affected by land area, the amount of use of seeds, fertilizers, pesticides, labor, and others. If the Village Fund is used for the manufacture and improvement of infrastructure, then both increased production and income will be more indirectly affected through the improvement of village road infrastructure development, construction of concrete rebates, construction of farm roads, repair of irrigation networks, drainage, tertiary channels. , and retaining walls and training in agriculture (composting). All this causes better farming management such as optimal use of fertilizers and seeds because of easy access to land, frequent visits to the fields for plant maintenance, easy and quick access to eradicate pests so that indirectly increases production. With this convenience it also allows farmers to bring their vehicles to the land to transport production facilities and agricultural products (not carried) so that they can save and reduce transportation costs. Good farming roads also allow collector traders to have access to land, prices can compete from one trader to another so that the selling price of products increases, which in turn can increase farmers' income.

The results of this study were supported [19] who stated that with the launch of the Village Fund, the community and village government felt it was helped because the Village Fund made a significant contribution to village development, both from an economic, social and political perspective. From an economic point of view, accessibility and efficiency are increasing. Social impacts can strengthen social capital, and impact in the political sphere, providing great opportunities for community participation in development. Concerning agriculture, the community feels the benefits of the Village Fund in the form of smooth irrigation for rice fields and the transportation of agricultural products. With the smooth operation of the irrigation and transportation channels, the economic activities of the residents will run smoothly which is expected to improve the welfare of the residents. With the launch of the Village Fund, the community assessed that physical development had absorbed local labor, increased activities to improve village facilities and infrastructure, made the process of transporting harvest products easier, and maintenance of irrigation became increasingly controlled. Thus, the effect of physical development is to open up economic access to the community and job opportunities, which in turn will increase people's income. Village funds have a negative and significant effect on poverty in Java [20] Another research by [21]stated that Membership of professional groups exposes farmers to a wide range of ideas and thus gives farmers the opportunity to have better access to the markets.

Based on the results in Table 1, it can be seen that there has been an increase in production for all village typologies. In underdeveloped villages, the increase in rice production ranged from $3.8 \%$ to $33.3 \%$ (average increase of $16.38 \%$ ), in developing villages it was between $4.2 \%$ to $13.3 \%$ (average increase of $9.5 \%$ ), and in developed villages, it was between $7.7 \%$ and $23.8 \%$ (average increase of $13.4 \%$ ). The increase in corn production was $66.7 \%$. 
Table 1. Agricultural production and the percentage increase in the study sites are the indirect impacts of using the Village Fund

\begin{tabular}{|c|c|c|c|c|c|}
\hline \multirow{2}{*}{ No. } & \multirow[t]{2}{*}{ Location } & \multirow[t]{2}{*}{ Commodities } & \multicolumn{2}{|c|}{ Production $(\mathrm{Kg})$} & \multirow{2}{*}{$\begin{array}{c}\text { Increase } \\
(\%)\end{array}$} \\
\hline & & & 2014 & 2017 & \\
\hline \multirow[t]{4}{*}{1} & \multicolumn{5}{|l|}{ West Java Province } \\
\hline & a. Village Mekarmukti1 ${ }^{1)}$ & Rice & 4,500 & 5,000 & 11.1 \\
\hline & b. Village Binakarya2) & Rice & 4,800 & 5,000 & 4.2 \\
\hline & c. Village Pamekarsari ${ }^{3)}$ & Rice & 4,500 & 5,000 & 11.1 \\
\hline \multirow[t]{4}{*}{2} & \multicolumn{5}{|l|}{ DI Yogyakarta Province } \\
\hline & a. Village Melikan ${ }^{1)}$ & Rice & 4,760 & 5,176 & 8.7 \\
\hline & b. Village Margoluwih ${ }^{2}$ & Rice & 4500 & 5,000 & 11.1 \\
\hline & c. Village Sardonoharjo ${ }^{3)}$ & Rice & 4,500 & 5,000 & 11.1 \\
\hline \multirow[t]{4}{*}{3} & \multicolumn{5}{|l|}{ Riau Province } \\
\hline & a. Village Gobah ${ }^{1)}$ & Rice & 4,000 & 5,000 & 25.0 \\
\hline & b. Village Kualu Nenas ${ }^{2)^{*}}$ & Pineapple & & & \\
\hline & c. Village Bungaraya ${ }^{3)}$ & Rice & 6,500 & 7,000 & 7.7 \\
\hline \multirow[t]{4}{*}{4} & \multicolumn{5}{|l|}{ Kalimantan Timur Province } \\
\hline & a. Village Loa Lepu ${ }^{1)}$ & Rice & 5,300 & 5,500 & 3.8 \\
\hline & b. Village Bukit Pariaman ${ }^{2}$ & Rice & 6,000 & 6,800 & 13.3 \\
\hline & c. Village Loa Kulu Kota ${ }^{3)}$ & Rice & 4,200 & 5,200 & 23.8 \\
\hline \multirow[t]{4}{*}{5} & \multicolumn{5}{|l|}{ Provinsi Gorontalo } \\
\hline & a. Village Duwanga ${ }^{1)}$ & Rice & 3,000 & 4,000 & 33.3 \\
\hline & b. Village Daenaa ${ }^{2)}$ & Corn & 3,000 & 5,000 & 66.7 \\
\hline & c. Village Hulawa ${ }^{3)}$ & Tomato & 40,000 & 40,000 & $\begin{array}{r}\text { Relatively } \\
\text { fix }\end{array}$ \\
\hline
\end{tabular}

Note ${ }^{1)}$ underdeveloped village; ${ }^{2)}$ thriving village; ${ }^{3)}$ advanced village

*Pineapple production, first and second harvests, 17872 fruit, six months later harvest once a week 200-500

Source: Primary data (2018), processed

Table 2 shows the magnitude of the increase in the income of rice farmers in the 15 sample villages. Calculated income is income over cash costs, meaning that the calculated costs are costs incurred in cash without calculating fixed costs and opportunity costs. Based on the results in Table 2, it can be seen that there is an indirect increase in income in various village typologies. In underdeveloped villages, the increase in income ranged from $12.8 \%$ to $35.8 \%$, the increase in income in developing villages was between $9.2 \%$ and $24.1 \%$ and in developed villages, there was an increase in income between $7.0 \%$ to $31.9 \%$.

The findings of this study are confirmed by the research results of [22] which concluded that there are differences in community income before and after the Village Fund. The income of the community after the Village Fund was greater than before the Village Fund. This is due to many developments carried out in rural areas that have had a positive impact on employment and providing business capital to Village-Owned Enterprises. The results of these studies conclude that the Village Fund provides positive benefits to increase village development and economy. The economy of the people in Pineleng District improved after 
the Village Fund program was implemented. This is due to an increase in infrastructure in the form of construction of agricultural roads, so that access to transportation from the plantation location is easier, thus accelerating the process of selling agricultural products. These results are in line with research [23] that infrastructure development in ECOWAS countries affects agricultural production and creates jobs. Absorption of local government budgets (including village funds) can increase the human development index, and reduce unemployment in the next two and three years [24], The results of the study [25] show that public investment in physical infrastructure (rural roads, electricity and village irrigation) and social infrastructure (rural education and rural health) has a positive and significant effect on TFP.

Table 2. Income and the percentage increase in agricultural commodities at the study location were the indirect impacts of the use of Village Funds

\begin{tabular}{|c|c|c|c|c|c|}
\hline \multirow[t]{2}{*}{ No. } & \multirow[t]{2}{*}{ Location } & \multirow[t]{2}{*}{ Commodities } & \multicolumn{2}{|c|}{ Income (IDR) } & \multirow{2}{*}{$\begin{array}{c}\text { Increase } \\
(\%)\end{array}$} \\
\hline & & & 2014 & 2017 & \\
\hline \multirow[t]{4}{*}{1} & \multicolumn{5}{|l|}{ West Java Province } \\
\hline & d. Village Mekarmukti ${ }^{1)}$ & Rice & $12,300,000$ & $15,800,000$ & 28.5 \\
\hline & e. Village Binakarya ${ }^{2)}$ & Rice & $19,928,570$ & $24,178,570$ & 21.3 \\
\hline & f. Village Pamekarsari ${ }^{3)}$ & Rice & $9,937,000$ & $12,421,500$ & 25.0 \\
\hline \multirow[t]{4}{*}{2} & \multicolumn{5}{|l|}{ DI Yogyakarta Province } \\
\hline & b. Village Melikan ${ }^{1)}$ & Rice & $23,774,000$ & $26,816,400$ & 12.8 \\
\hline & b. Village Margoluwih²) & Rice & $10,500,000$ & $11,470,000$ & 9.2 \\
\hline & d. Village Sardonoharjo ${ }^{3)}$ & Rice & $10,500,000$ & $11,232,000$ & 7.0 \\
\hline \multirow[t]{4}{*}{3} & \multicolumn{5}{|l|}{ Riau Province } \\
\hline & d. Village Gobah ${ }^{1)}$ & Rice & Consumption & Consumption & \\
\hline & e. Village Kualu Nenas ${ }^{2)^{*}}$ & Pineapple & $17,830,000$ & $21,446,000$ & 20.3 \\
\hline & f. Village Bungaraya ${ }^{3)}$ & Rice & $16,415,000$ & $19,215,000$ & 17.1 \\
\hline \multirow[t]{4}{*}{4} & \multicolumn{5}{|l|}{ Kalimantan Timur Province } \\
\hline & d. Village Loa Lepu ${ }^{1)}$ & Rice & $16,100,000$ & $21,865,000$ & 35.8 \\
\hline & e. Village Bukit Pariaman ${ }^{2)}$ & Rice & $17,800,000$ & $22,085,000$ & 24.1 \\
\hline & f. Village Loa Kulu Kota3) & Rice & $10,540,000$ & $13,900,000$ & 31.9 \\
\hline \multirow[t]{4}{*}{5} & \multicolumn{5}{|l|}{ Provinsi Gorontalo } \\
\hline & d. Village Duwanga ${ }^{1)}$ & Rice & $13,250,000$ & $16,150,000$ & 21.9 \\
\hline & e. Village Daenaa ${ }^{2)}$ & Corn & $23,864,500$ & $28,864,500$ & 21.0 \\
\hline & f. Village Hulawa ${ }^{3}$ & Tomato & $117,000,000$ & $132,000,000$ & 12.8 \\
\hline
\end{tabular}

Note: ${ }^{1)}$ underdeveloped village; ${ }^{2)}$ thriving village; ${ }^{3)}$ advanced village

Source: Indraningsih et al. (2018)

Transportation of production facilities and agricultural products in underdeveloped and developing areas with poor road access must be carried out. This results in relatively higher input costs, limited plant maintenance, and a lower work ethic. With the development of infrastructure (farming roads, including repair of irrigation channels), the cropping pattern has changed from two crops (IP 200) to three crops (IP 300). This causes an increase in production. Farmers' access to land to rice fields is easier so that farming management is better. When there is an attack by a pest, the prevention will be faster and the transportation 
will run smoothly, both for the transportation of production facilities and for marketing the products. The yields that used to be carried, are now easier because you can use two and fourwheeled vehicles to land. Thus the cost of the shoulder can be saved by using one's motorbike. This development facilitates the mobility of transportation for agricultural production facilities and agricultural products.

The results[26] showed that village funds in Pomahan village were allocated for sectors implementation of $55 \%$, in the field of village administration $27 \%$, community empowerment $12 \%$ and community development sector $5 \%$. Impact of village funds has driven economic growth and empowered village communities so that they can increase income and welfare. However, the development of facilities provided many indirect benefits to the farmers, including helping them tackle the problem of post-harvest losses [27] The infrastructure project in Thiruvananthapuram is considered successful by users. This success is linked to the transport sector with a higher level of engagement and awareness from users [28]

The Village Fund, which is used for the development of irrigation, tertiary channels, and drainage, also has an indirect impact on increasing agricultural production. Farmers feel the benefits of the Village Fund in the form of smooth irrigation for rice fields. With the smooth operation of the irrigation canals, farmers 'economic activities are particularly good which in turn can increase agricultural production and farmers' income.

One of the farmers interviewed in Bungaraya Village stated that with better infrastructure, the enthusiasm of farmers to go to the fields has increased, even at midnight they can go to the rice fields, used to ride bicycles, now motorbikes and cars can reach the rice fields. This causes the price of rice to increase because traders can enter the place so that prices are competitive among traders. In pineapple farming in Kualu Nenas Village, farming roads help a lot in increasing the price of pineapples because traders can come directly to the land and make buying and selling transactions on the spot. Table 3 is an example of the socioeconomic impact of the Village Fund in Mekarmukti Village.

Table 3. Socio-economic conditions before and after the Village Fund was rolled out in Mekarmukti Village, Cibalong District, Garut Regency, 2018

\begin{tabular}{|l|l|l|l|}
\hline No. & \multicolumn{1}{|c|}{ Description } & \multicolumn{1}{|c|}{ Before (2014) } & \multicolumn{1}{|c|}{ After (2017) } \\
\hline 1. & Land area & Arable land is about 1 ha & $\begin{array}{l}\text { Arable land can be up to } \\
1.5 \mathrm{Ha}\end{array}$ \\
\hline 2. & Cropping patterns & Rice-Secondary crops & Rice-rice or rice-rice-rice \\
\hline 3. & $\begin{array}{l}\text { Access to production } \\
\text { facilities kiosks }\end{array}$ & $\begin{array}{l}\text { Difficult to reach, because } \\
\text { the road is still not good }\end{array}$ & $\begin{array}{l}\text { It's easier because the road } \\
\text { has been repaired } \\
\text { (concrete rebate) }\end{array}$ \\
\hline 4. & $\begin{array}{l}\text { Transportation of production } \\
\text { facilities }\end{array}$ & $\begin{array}{l}\text { Carried, cannot use } \\
\text { motorized vehicles }\end{array}$ & $\begin{array}{l}\text { It's easier, can use a } \\
\text { motorized vehicle, cheaper } \\
\text { transportation costs }\end{array}$ \\
\hline 5. & Mileage to market & $\begin{array}{l}\text { Access to old markets. There } \\
\text { is no car/goods } \\
\text { transportation. } \\
\text { Transportation to transport } \\
\text { crops and fruits (banana) can } \\
\text { take up to two nights (until } \\
\text { the banana is ripe) }\end{array}$ & $\begin{array}{l}\text { Access to markets faster. } \\
\text { Goods/car transportation } \\
\text { already } \\
\text { Transportation to transport } \\
\text { crops and fruits (bananas) } \\
\text { takes a few hours, so } \\
\text { marketing is better }\end{array}$ \\
\hline 6. & Transportation costs & $\begin{array}{l}\text { The cost of production } \\
\text { facilities is expensive } \\
\text { because you have to bear it to } \\
\text { get to the fields }\end{array}$ & $\begin{array}{l}\text { Transportation costs are } \\
\text { cheaper to transport } \\
\text { agricultural products and } \\
\text { purchase production } \\
\text { facilities }\end{array}$ \\
\hline
\end{tabular}

Source: Indraningsih et al. (2018) 
The results of this study are supported by the findings of research by[29] indicate that Village Funds are used for infrastructure development and empowerment, have a significant impact on increasing income, reducing gender inequality and poverty, although their contribution is very low. From the aspect of micro and small business development, serves as a mediator to achieve the target of increasing per capita expenditure, reducing poverty, which contributes more than the target without a mediator. The results [30] show that rural infrastructure has a positive and significant effect on reducing production costs. That improving infrastructure will enable promotion to conserve resources and environmental performance, especially for farmers with high-cost production.

\subsection{The Role of Village Funds in Supporting Sustainable Agricultural Development}

Agricultural development will form an agroecosystem consisting of the complexity of organisms in agricultural areas or areas planted and transformed by various kinds of human activities for the benefit of the agricultural sector, industry and other activities [6]. If agriculture is an activity of human intervention in the development of plant and animal life so that they can better meet their needs, then in agricultural development, the increase in the amount of capital and skills is intended to increase this intervention.

The results of research [31] conducted in the Maldives indicated that according to 373 stakeholders (farmers) the term agriculture sustainability is closely related to profitability. This is supported by increased production capacity driven by better access to inputs and markets. Farmers claim that the best means of achieving increased capacity for profit are individualistic farming activities, either as a single farmer or as a family farm unit. Institutional farming capacity building interventions have a softer focus on profitability. These interventions have generally focused on improving the livelihoods of islanders and building food security through the formation of collective producers and marketing cooperatives. Furthermore [32] states that in Zimbabwe, intensive spending on infrastructure will result in sustainable food productivity and production.

\section{CONCLUSIONS AND POLICY IMPLICATIONS}

\subsection{Conclusion}

In all studied villages, the special allocation of the Village Fund for the agricultural sector, such as the provision of fertilizers, medicines, agricultural machinery, and so on, is relatively small, only around IDR 17 million for the purchase of horticultural seeds and food diversification. The Village Fund is more focused on infrastructure development, especially roads to expedite rural economic activities, increase farmers 'and agricultural product traders' access to markets. Both the increase in production and income are more indirectly caused by the indirect impact of allocating Village Funds through the development of better village road infrastructure, construction of concrete rebates, construction of farm roads, repair of irrigation networks, drainage, tertiary channels and retaining walls and field training. Agriculture (composting). All this causes better farm management.

The implementation of the Village Fund has a direct or indirect effect on increasing farmers' production and income. There are differences in the increase in production and income in the three village typologies. With the improvement of infrastructure and improvement of farming facilities and infrastructure, the process of transporting production facilities and crop yields will become easier, which affects reducing production costs and increasing selling prices. Besides, the role of the Village Fund can also encourage agricultural development in rural areas to become more dynamic and sustainable. 


\subsection{Policy Implications}

1. There is a need for capital participation in Village-Owned Enterprises, extension workers, and peasants to make a business plan. Village funds need to be allocated for agricultural activities, included in the APBDes with an empowerment budget post with land optimization activities.

2. In the typology of underdeveloped villages with quite difficult geographical conditions, most of the farm roads are still land, it is necessary to have road paving so that transportation to transport production facilities and agricultural products becomes easier as well as rehabilitation of irrigation networks, and construction of soil retaining walls.

3. In addition to infrastructure development, the Village Fund needs to be allocated in the future for community economic empowerment, such as training in agricultural, livestock, and fishery skills by the local potential of the village. This empowerment effort is expected to run more sustainably in agricultural development.

\section{References}

1. E. P. Yudha, B. Juanda, L. M. Kolopaking, and R. A. Kinseng, J. Stud. Res. Hum. Demogr. 14, 125 (2020).

2. E. P. Sanjoyo, in Kementrian Desa Pembang. Drh. Tertinggal (2017).

3. S. F. Alipour, H. M. Boshrabadi, M. R. Z. Moherjerdi, and D. A. Hayati, Sustainability 10, (2018).

4. J. H. Jo, T. W. Roh, S.Kim, Y. C. Youn, M. S. Park, K. J. Han, and E.K.Jang, Sustainability 7, (2015).

5. M. Hajer, M.Nilson, K. Raworth, P.Bakker, F.Berkhout, Y. d. Boer, J. Rokestrom, K.Ludwig, and M.Kok, Sustainability 7, 1651 (2015).

6. E.S. Sudalmi, J. Inov. Pertan. 9, 15 (2010).

7. Statistical Bureau, Est Java in Figure (2019).

8. T.Patankar, P.Jadhav, S.Pulaware, K.Bagate, and V.Mundhe, Int. J. Adv. Sci. Technol. 29, 2658 (2020).

9. D. Sudaryati and S.Heriningsih, Int. J. Progress. Sci. Technol. 13, 267 (2019).

10. T. D. Fatwmawati, W. Prasetyoa, and S. M. Wardayati, Int. J. Res. Sci. Manag. 5, 23 (2018).

11. Ak. S. P. R. Indonesia, Laporan Veirfikasi Lapangan Pembangunan Desa Pasca Pemberlakuan UU 6/2014 Tentang Desa (2017).

12. S. A. Imawan and E. A. Purwanto, Policy Gov. Rev. 4, 14 (2020).

13. M. A. Arham and R. Hatu, J. Asian Financ. Econ. Bussiness 7, 433 (2020).

14. C. Apipooyanon, S. Szaboo, T. W. Tsusaka, K.Leeson, and E.Gunawan, Outlook Agric. 10, (2020).

15. J.Ochieng, K. Lilian, and M. Mathenge., NJAS-Wageningen J. Life Sci. 77, 71 (2016).

16. N. A. Husen, T.K.Loos, and K.H.A.Siddiq, Am. J. Rural Dev. 3, 65 (2017).

17. W. Petco, S. Szabo, and K. Kusakabe, Sustainability 11, 1 (2019).

18. E. Gunawan and A. J.K.M. Kuwornu, Sustainabiliaaty 11, 2019 (2019).

19. A. Sofianto, Matra Pembaruan 1, 23 (2017).

20. A. Hermawan, Istoqomah, and A. A. Ahmad, Int. Conf. Rural Dev. Enterpreneursh. 5, 1 (2019).

21. D. Joviece, L.Jeremie, L.Milicevie, and A. A. Zeremski, Econ. Agric. 61, 347 (2014).

22. F. V. Tangkumahat, V. V. J. Panelewen, and A. D. P. Mirah, Agri-Sosio Ekon. Unsrat 13, 335 (2017). 
23. E. K. Richardson, N. C.Nkalu, J. Francis, C. Idenyi, and W. O. Arazu, Sustain. Futur. 100010 (2020).

24. H. Habbe, Int. J. Sci. Technol. Res. 9, 1 (2020).

25. N. Nadeem, K. Mushtaq, and M. Ishaq, Pakistan J. Life Soc. Sci. 9, 153 (2011).

26. Zakariya, Int. J. Innov. Creat. Chang. 13, 1726 (2020).

27. M.Sheahan and C. B. Barret, Food Policy 70, 1 (2017).

28. S.Kohandath and H.haran, IJITEE 9, 30 (2020).

29. H. Triyowati, Y. Masnita, and Khomsiyah, Int. J. Adv. Sci. Technol. 49, 493 (2020).

30. Q. Wu, X. Guan, J. Zhang, and Y. Xu, Int. J. Environ. Res. Public Heal. 16, 3493 (2019).

31. P. A. van Driessche, Int J Agric. Sustain. 11, 537 (2020).

32. W. Munyanyi, Russ. J. Agric. Socio- Econ. Sci. 12, 13 (2013). 